\title{
SZANSE WYCHOWANIA KU WARTOŚCIOM W AKTUALNEJ PODSTAWIE PROGRAMOWEJ W ŚWIETLE INTEGRALNEGO ROZWOJU DZIECKA W MŁODSZYM WIEKU SZKOLNYM
}

\begin{abstract}
Streszczenie: W przedstawionym opracowaniu został poruszony problem dotyczący wychowania ku wartościom dzieci w młodszym wieku szkolnym w świetle ich integralnego rozwoju, ich wzrastania w poszczególnych sferach (biologicznej, psychologicznej, socjologicznej, kulturologicznej i światopoglądowej). Istotne jest tutaj nie tylko wzrastanie poszczególnych warstw, ale także ich integracja. Przedstawiono także grupy wartości związane z poszczególnymi warstwami rozwojowymi człowieka. Z warstwą biologiczną związane są wartości hedonistyczne, witalne i materialne; z warstwą psychologiczną - głównie wartości poznawcze; z warstwą społeczną - wartości moralno-społeczne; z warstwą kulturologiczną - wartości kulturowe, z warstwą światopoglądową - wartości ostateczne. Grupy te stanowiły podstawę do dokonania analizy treści zawartych w obowiązującej podstawie programowej dla I etapu edukacyjnego w celu odpowiedzi na postawione w kontekście tematu opracowania pytanie: jakie szanse wychowania ku wartościom stwarza aktualne podstawa programowa w świetle integralnego rozwoju dziecka w młodszym wieku szkolnym?
\end{abstract}

Słowa kluczowe: integralny rozwój, wychowanie ku wartościom, edukacja wczesnoszkolna

\section{WPROWADZENIE}

Wychowanie ku wartościom stanowi kluczowe zadanie i cel wychowania na wszystkich etapach rozwoju człowieka, także w wieku wczesnoszkolnym. Dotyczy ono wychowania zarówno w wymiarze jednostkowym, jak i społecznym. Jan Paweł II podkreśla, że „wartości są podstawą, która nie tylko decyduje o życiu, ale także określa linie postępowania i strategie, które budują życie w społeczeństwie. Nie można oddzielać od siebie wartości osobistych i wartości społecznych" (Jan Paweł II 1991, 
s. 144). Powinność wychowania ku wartościom spoczywa zarówno na wychowawcach (polega na ukazywaniu wartości), jak i wychowankach (polega na wybieraniu wartości i ich urzeczywistnianiu w projekcie życia - tak osobistego, jak i społecznego).

W kontekście tematu opracowania postawiono pytanie, jakie szanse wychowania ku wartościom stwarza podstawa programowa dla I etapu edukacyjnego w świetle integralnego rozwoju dziecka. Rozwiązanie tak sformułowanego problemu opierać się będzie na analizie trzech podstawowych zagadnień, jakimi są:

- integralny rozwój dziecka w młodszym wieku szkolnym,

- wychowanie ku wartościom,

- analiza treści podstawy programowej dla I etapu edukacyjnego pod kątem ukazania szans i możliwości, jakie stwarza obowiązująca podstawa programowa w zakresie wychowania ku wartościom.

\section{INTEGRALNY ROZWÓJ DZIECKA W MŁODSZYM WIEKU SZKOLNYM}

Integralny rozwój dziecka w młodszym wieku szkolnym omówiony zostanie (ze względu na formę opracowania w skrótowej formie) głównie w oparciu na warstwicowej teorii rozwoju człowieka Stefana Kunowskiego. Punktem wyjścia poniższych rozważań będzie definicja Krystyny Ostrowskiej, według której „integralny rozwój człowieka to całościowy zewnętrzny i wewnętrzny rozwój człowieka i przystosowanie do życia według przyjętego wzoru” (Ostrowska 1994, s. 14). Powyższą definicję dookreśla Krystyna Chałas, pisząc:

Ów integralny rozwój stanowi priorytetowy cel zabiegów edukacyjnych. Przez integralny rozwój człowieka będziemy rozumieć rozwój wszystkich warstw człowieka, wzajemnie ze sobą zintegrowanych i przenikających się, prowadzących w projekcie życia do pełni człowieczeństwa (Chałas 2007, s. 11).

Kunowski w teorii warstwicowej rozwoju człowieka wskazuje na pięć warstwic: biologiczną, psychologiczną, socjologiczną, kulturologiczną i światopoglądową, czyli duchową (Kunowski 2004, s. 197), które jednocześnie wyznaczają pięć okresów rozwojowych człowieka. Należy podkreślić, że nie są to struktury odrębne, lecz podlegają one integracji. Ukształtowana wcześniej warstwa stanowi bazę (podłoże), na której może rozwinąć się następna. Poniżej zostanie przedstawiona krótka charakterystyka rozwoju poszczególnych warstwic w odniesieniu do dziecka w młodszym wieku szkolnym (por. Buk-Cegiełka 2013, s. 94-96).

Rozwój fizyczny dziecka w wieku wczesnoszkolnym to przede wszystkim zmiany w wielkości i proporcjach ciała, kośćca, mięśni, narządów wewnętrznych 
(głównie centralnego układu nerwowego), rozwój motoryczny (w zakresie dużej i małej motoryki). W obszarze warstwy psychologicznej w wieku wczesnoszkolnym rozwijają się procesy poznawcze, takie jak: myślenie, uwaga, pamięć, spostrzeganie, uczenie się. Procesy poznawcze w młodszym wieku szkolnym stają się, $\mathrm{w}$ porównaniu $\mathrm{z}$ wiekiem przedszkolnym, bardziej świadome, kierowane i kontrolowane przez dziecko. Myślenie logiczne zajmuje w tym czasie miejsce myślenia przedoperacyjnego, charakterystycznego dla wieku przedszkolnego. Spostrzeganie z mimowolnego staje się także bardziej świadome i celowe. Rozwój uwagi dowolnej, od której zależy rozwój pamięci i uczenia się, pozwala dziecku skupić się na wykonywanych zadaniach na tyle długo, aby podołać obowiązkom szkolnym. Dla dalszych analiz istotne znaczenie ma występowanie zaciekawień w wieku wczesnoszkolnym, które w wieku dorastania mogą przerodzić się w długotrwałe zainteresowania.

Pozostałe warstwy (społeczna, kulturologiczna i światopoglądowa), nadbudowujące się nad warstwą biologiczną i psychologiczną, intensywnie rozwijać się będą i osiągną swoją dojrzałość w późniejszym okresie. W wieku wczesnoszkolnym należy pamiętać o podjęciu działań, które w przyszłości zaowocują prawidłowym ukształtowaniem tych warstw.

Rozwój warstwy społecznej przejawia się rozwojem kontaktów z rówieśnikami, nawiązywaniem przyjaźni i sympatii, które wynikają ze zmian zachodzących w osobowości wychowanka. Dzięki nim dziecko może uczestniczyć w życiu społecznym. Przejawia się to w przyjmowaniu różnorodnych ról społecznych, wynikających ze zmiany i rozszerzenia środowiska społecznego (rozpoczęcie nauki w szkole). Dziecko w młodszym wieku szkolnym przygotowuje się do włączania w późniejszym okresie w coraz szersze grupy społeczne. Rozwój społeczny ściśle wiąże się z rozwojem moralnym wychowanka. W młodszym wieku szkolnym - zgodnie z teorią Lawrence'a Kohlberga - znajduje się on na poziomie konwencjonalnym. W tym czasie dziecko przyjmuje ogólne normy oraz zasady społeczne za własne, a także uznaje je za sprawiedliwe i słuszne.

Dbałość o przyszły rozwój warstwy kulturologicznej w młodszym wieku szkolnym polega na umożliwianiu dziecku kontaktu z dziełami sztuki, kształtowaniu wrażliwości estetycznej oraz rozwijaniu twórczej aktywności dziecka. Jest to taki okres w życiu, kiedy dziecko może po raz pierwszy poczuć się artystą. Zajęcia plastyczne, muzyczne, techniczne, językowe pozwalają na wyrażanie siebie, odkrywanie własnych talentów, jak również rozwijają zamiłowanie do sztuki. Uczestnictwo w życiu kulturowym sprowadza się zatem nie tylko do biernego uczestnictwa w świecie kultury i sztuki, ale także do jego tworzenia. Na tym etapie dostarcza się dziecku wiele możliwości rozwoju warstwy kulturologicznej, chociażby przez organizację przedstawień i akademii szkolnych, wyjść do teatru, kina, muzeum. 
Warstwa światopoglądowa dziecka w młodszym wieku szkolnym rozwija się głównie za przyczyną przykładu rodziców, rówieśników, nauczycieli, katechetów. Dzieci uczestniczą w formach rozwoju duchowego początkowo głównie z nakazu rodziców. Już od pierwszej klasy szkoły podstawowej następuje zewnętrzne stymulowanie rozwoju duchowo-religijnego w szkole za sprawą przygotowywania uczniów do przyjęcia I Komunii Świętej. A to z kolei wiąże się z uczestnictwem w licznych nabożeństwach, spotkaniach mających rozwijać w młodym człowieku potrzebę zgłębiania własnej duchowości, religijności. Sprzyjająca dla rozwoju duchowości jest drzemiąca $w$ dzieciach ciekawość i chęć poznania nowych rzeczy oraz zjawisk. Jak podkreśla Chałas, „dziecko w wieku wczesnoszkolnym jest zdolne odróżnić dobro od zła, dokonać wartościowania i oceniania, poznawać prawdę o Bogu i drogę, która do Niego wiedzie" (Chałas 2014, s. 173).

Podsumowując, należy zauważyć, że wiek wczesnoszkolny charakteryzuje się specyfiką rozwojową poszczególnych warstw. W sposób najbardziej intensywny rozwija się warstwa biologiczna. Jej prawidłowy rozwój stanowi bazę i istotne źródło siły rozwojowej dla pozostałych warstw.

\section{WYCHOWANIE KU WARTOŚCIOM W ŚWIETLE INTEGRALNEGO ROZWOJU}

Kolejnym zagadnieniem poruszonym w opracowaniu jest wychowanie ku wartościom, które jako proces stanowi system czynności wychowawców i wychowanków wspomagający wychowanków w procesie urzeczywistniania wartości aż po ich tworzenie. Jak pisze Chałas, „pozytywny stosunek człowieka do wartości może się wyrażać w ich preferowaniu, a więc akceptacji, opowiadaniu za określoną ich hierarchią [...]. Można jednak preferować określone wartości, ale ich nie urzeczywistniać" (Chałas 2011, s. 69). Zadaniem wychowawców dziecka w młodszym wieku szkolnym jest ukazanie uczniom wartości, umożliwienie ich rozumienia, które staje się podstawą do ich wyboru jako preferowane, deklaratywne, aby w końcu wychowanek mógł je urzeczywistniać w swoim projekcie życia, budując własną i jednocześnie właściwą hierarchię wartości. Krystyna Ostrowska urzeczywistnianiem wartości określa „nabywanie takich ustosunkowań do wartości, że stają się one cechami naszej osobowości. Można więc o człowieku powiedzieć: sprawiedliwy, kochający, dobry, prawy, tolerancyjny, wierzący, etc." (Ostrowska 1994, s. 14). Jak pisze Władysław Cichoń, istnieją trzy grupy urzeczywistniania wartości przez człowieka. Są to warunki, które musi spełnić świat, który jest formami działalności ludzkiej, warunki, które musi spełnić człowiek będący podmiotem wartości oraz warunki, które sprzyjają rozwojowi człowieka (Cichoń 1996, s. 55). 
W kontekście tematu opracowania istotna jest ta trzecia grupa warunków, która dotyczy rozwoju człowieka, ze szczególnym uwzględnieniem jego integralności. Jak podkreśla badacz, wychowanie ku wartościom oddziaływać winno na wszystkie sfery rozwoju i funkcjonowania wychowanka, powinno stanowić podstawę osobowego wzrastania, integralnego rozwoju i wychowania, dążenia do pełni człowieczeństwa (zob. Cichoń 1996, s. 115).

Jak było powiedziane wcześniej, integralny rozwój człowieka to jego wzrastanie w poszczególnych sferach: biologicznej, psychologicznej, socjologicznej, kulturologicznej i światopoglądowej oraz ich integracja. Jak pisze Chałas:

Każda urzeczywistniana wartość „wpisuje się” w sposób szczególny swą mocą sprawczą w określoną warstwę, ale też „porusza” inne warstwy. To wielopłaszczyznowe „bytowanie” poszczególnych grup wartości prowadzi do integracji sfer rozwoju człowieka. W ten to sposób wartości dynamizują i scalają obraz człowieka (Chałas 2011, s. 71).

Z uwzględnieniem znaczenia wartości w integralnym rozwoju człowieka poniżej przedstawione zostaną grupy wartości związane z poszczególnymi warstwami rozwojowymi człowieka.

Z rozwojem warstwy biologicznej związane są wartości hedonistyczne, witalne i materialne. Do głównych wartości witalnych zaliczyć należy dbałość o zdrowie i bezpieczeństwo, prawidłowe odżywianie, prowadzenie zdrowego trybu życia, ruch, wypoczynek, sen, siły życiowe. Wartości hedonistyczne (przyjemnościowe) związane są z łatwym i przyjemnym życiem. Jak pisze Chałas, ich urzeczywistnianie zapewnia „radość, zadowolenie, buduje świat przyjemności - ważne czynniki zdrowia psychicznego" (Chałas 2011, s. 71). Wartości materialne związane są z dobrami, które pozwalają człowiekowi żyć na odpowiednim poziomie, czynią życie prostszym. Ważne jest, aby dzieci w wieku wczesnoszkolnym dbały o zdrowie na miarę swoich możliwości: ubierały się odpowiednio do pogody, miały świadomość znaczenia zdrowego odżywiania, niebezpieczeństw i zagrożeń zarówno ze strony ludzi, jak i zwierząt, roślin, zjawisk atmosferycznych, bawiły się bezpiecznie, dbały o higienę, pamiętały o odpoczynku. Istotne jest również ukazanie uczniom właściwego i rozsądnego podejścia do rzeczy i dóbr materialnych.

Z warstwą psychologiczną związane są głównie wartości poznawcze: wiedza, mądrość, nauka, odkrywczość, twórczość (zob. Denek 2000, s. 37-39). Jak pisze Chałas: „Przyjęcie przez młodego człowieka wartości nauki, pozytywny stosunek do procesu kształcenia i samokształcenia, zaangażowanie w zdobywanie umiejętności stanowi czynnik rozwoju myślenia, wyobraźni, pamięci, uwagi - elementów stanowiących podstawę rozwoju warstwy psychologicznej” (Chałas 2011, s. 72). Rozwijanie u dzieci ciekawości poznawczej, aktywności twórczej, kreatywności, 
otwartości na wiedzę i chęci samodzielnego jej odkrywania i zdobywania służyć będzie rozwojowi tej warstwy.

W warstwę socjologiczną wpisują się wartości moralno-społeczne. Grupę wartości moralnych stanowią: prawość, wierność, poczucie odpowiedzialności, poszanowanie prawdy, dobroć (zob. Hidebrand i in. 1984, s. 14-52). Do wartości społecznych zalicza się natomiast: ojczyzna, naród, Kościól, patriotyzm, niepodległość, praworządność, tradycja narodowa, prawa człowieka, godność człowieka, wolność, pokój, tolerancja, sprawiedliwość, równość społeczna, zabezpieczenie społeczne, demokracja, solidarność (zob. Piwowarski 1993, s. 188).

„Urzeczywistnianie wartości moralnych skutkuje tożsamością społeczną, potrzebą zajęcia określonej pozycji w społeczności, co integralnie jest związane z określonym spektrum wykonywanych zadań" (Chałas 2011, s. 72). Przyjmowanie i urzeczywistnianie wyżej wymienionych wartości pozwala człowiekowi na życie w społeczeństwie i dla społeczeństwa. Wśród uczniów klas I-III będzie to współpraca w grupie rówieśniczej, klasie szkolnej, podejmowanie działań z drugim człowiekiem i dla drugiego człowieka. Odpowiedzialne pełnienie ról społecznych - dziecka $\mathrm{w}$ rodzinie, ucznia, kolegi, przyjaciela - przygotowuje do przyszłego dorosłego życia.

Sfera kulturologiczna to wartości kulturowe, które „stanowią rdzeń kultury, niezbędne środowisko życia rozwoju człowieka” (Chałas 2011, s. 73). „Dynamizują myślenie, wyobraźnię twórczą, "wołają« o rozwój talentów. »Wołają" poprzez swe piękno o podjęcie procesu twórczego na rzecz rozwoju kultury" (tamże). Wrażliwość na piękno wzbogaca człowieka, czyni go piękniejszym. Ważne jest, aby dziecko w wieku wczesnoszkolnym miało możliwość poznawania dzieł sztuki, miało z nią kontakt oraz samo mogło rozwijać własną aktywność twórczą.

Natomiast $\mathrm{z}$ warstwą światopoglądową związane są wartości ostateczne. Naczelną wartością jest szczęście. Według Pawła Skrzydlewskiego jest to „cel ludzkiego życia osiągany za sprawą pełnej aktualizacji osobowych potencjalności człowieka; zjednoczenia człowieka z Bogiem, będącym źródłem miłości i dobra; różne od radości, szczęśliwości, pomyślności oraz posiadania rzeczy materialnych" (Skrzydlewski 2016, s. 1121). Chałas podkreśla, że dla człowieka, który jest osobą niewierzącą, będzie ono dotyczyło szczęścia osiąganego w życiu tu na ziemi, natomiast dla ludzi wierzących odnosić się będzie do szczęścia wiecznego, którego osiągnięcie możliwe jest przez realizację wartości religijnych, takich jak: wiara w Boga, religia, nadzieja, miłość, modlitwa, świętość (zob. Chałas 2011, s. 73). W wieku wczesnoszkolnym następuje regularna katechizacja, stanowiąca uzupełnienie dla wzrastania $\mathrm{w}$ wierze $\mathrm{w}$ domu rodzinnym, spełnianie praktyk religijnych przez modlitwę, udział w sakramentach.

Należy jeszcze raz podkreślić, że wartości wpisane w poszczególne sfery rozwoju człowieka i ich urzeczywistnianie skutkuje nie tylko rozwojem pojedynczych 
warstw, ale także odnosi się do pozostałych, integrując je ze sobą, kształtując człowieka jako osobę.

\section{TREŚCI PROGRAMOWE STWARZAJĄCE SZANSE WYCHOWANIA KU WARTOŚCIOM}

W kontekście tematu opracowania podjęto próbę odpowiedzi na pytanie, jakie szanse wychowania ku wartościom stwarza aktualna podstawa programowa w świetle integralnego rozwoju dziecka w młodszym wieku szkolnym. W celu odpowiedzi na to pytanie dokonano analizy treści zawartych w obowiązującej podstawie programowej dla I etapu edukacyjnego pod kątem możliwości wychowania ku wartościom dziecka w młodszym wieku szkolnym w odniesieniu do poszczególnych sfer jego rozwoju.

Wartości witalne, hedonistyczne i materialne wpisujące się w warstwę biologiczną człowieka możemy odnaleźć wśród treści podstawy programowej w takich obszarach edukacyjnych, jak: edukacja społeczna, przyrodnicza, zajęcia komputerowe, wychowanie fizyczne i edukacja zdrowotna, zajęcia techniczne czy etyka.

Wychowanie do wartości zdrowia - dbałości o zdrowie i bezpieczeństwo, siły życiowe, prowadzenie zdrowego trybu życia - możliwe jest na:

- Edukacji przyrodniczej:

- Uczeń: posługuje się numerami telefonów alarmowych, formułuje komunikat - wezwanie o pomoc: policji, pogotowia ratunkowego, straży pożarnej; reaguje stosownym zachowaniem w sytuacji zagrożenia bezpieczeństwa, zdrowia jego lub innej osoby; ma świadomość znaczenia odpowiedniej diety dla utrzymania zdrowia, ogranicza spożywanie posiłków o niskich wartościach odżywczych i niezdrowych, zachowuje umiar w spożywaniu produktów słodzonych, zna konsekwencje zjadania ich w nadmiarze; przygotowuje posiłki służące utrzymaniu zdrowia; ubiera się odpowiednio do stanu pogody; stosuje przepisy bezpieczeństwa w ruchu drogowym i miejscach publicznych; stosuje się do zasad bezpieczeństwa w szkole, odnajduje drogę ewakuacyjną, rozpoznaje znaki i symbole informujące o różnych rodzajach niebezpieczeństw oraz zachowuje się zgodnie $\mathrm{z}$ informacją $\mathrm{w}$ nich zawartą; stosuje zasady bezpiecznej zabawy w różnych warunkach i porach roku; ma świadomość istnienia zagrożeń ze środowiska naturalnego, np. nagła zmiana pogody, huragan, ulewne deszcze, burza, susza oraz ich następstwa: powódź, pożar, piorun; określa odpowiednie sposoby zachowania się człowieka w takich sytuacjach; ma świadomość, iż 
nieodpowiedzialne korzystanie $\mathrm{z}$ technologii ma wpływ na utratę zdrowia człowieka.

- Edukacji technicznej:

- Uczeń: organizuje pracę, wykorzystuje urządzenia techniczne i technologie; zwraca uwagę na zdrowie i zachowanie bezpieczeństwa, z uwzględnieniem selekcji informacji, wykonywania czynności użytecznych lub potrzebnych.

- Wychowaniu fizycznym:

- Uczeń: utrzymuje w czystości ręce i całe ciało, przebiera się przed zajęciami ruchowymi i po ich zakończeniu; wyjaśnia znaczenie ruchu w procesie utrzymania zdrowia (Dz.U. 2017, poz. 356).

W przytoczonych powyżej fragmentach podstawy programowej znajdujemy wiele treści dotyczących bezpieczeństwa i dbałości o bezpieczeństwo własne i innych, ochrony zdrowia, racjonalnego odżywiania, dbania o rozwój fizyczny i sprawność fizyczną.

W obowiązującej podstawie programowej trudno odnaleźć treści, których realizacja umożliwia właściwe ukazanie dóbr materialnych. Ich istotą nie jest wyłącznie posiadanie dóbr materialnych dla nich samych, ale ich instrumentalny charakter. Przez posiadanie dóbr życie człowieka jest łatwiejsze, daje możliwości dalszego wzrastania i rozwoju człowieka jako osoby. Wśród treści programowych równie trudno doszukać się oraz wskazać te, które nawiązywałby do wygodnego życia.

Kolejną grupę wartości stanowią te, które wpisują się w warstwę psychologiczną człowieka. Są to głównie wartości poznawcze.

Wiedza i mądrość wychowanka kształtowana jest i nabywana przez niego we wszystkich obszarach edukacyjnych. Ukazanie i poznanie istoty wartości nauki, wiedzy i mądrości wiąże się nierozerwalnie z odkrywczością i twórczością człowieka. W edukacji wczesnoszkolnej wartości te wpisują się m.in. w treści:

- Edukacji polonistycznej:

- Uczeń: wyszukuje w tekstach fragmenty według niego najpiękniejsze, najważniejsze, trudne do zrozumienia lub określone przez nauczyciela; korzysta z różnych źródeł informacji, np. atlasów, czasopism dla dzieci, słowników i encyklopedii czy zasobów internetu i rozwija swoje zainteresowania; wykorzystuje nabyte umiejętności do rozwiązywania problemów i eksploracji świata, dbając o własny rozwój i tworząc indywidualne strategie uczenia się.

- Edukacji przyrodniczej:

- Uczeń: planuje, wykonuje proste obserwacje, doświadczenia i eksperymenty dotyczące obiektów i zjawisk przyrodniczych, tworzy notatki 
z obserwacji, wyjaśnia istotę obserwowanych zjawisk według procesu przyczynowo-skutkowego i czasowego.

- Edukacji muzycznej:

- Uczeń: interpretuje ruchem schematy rytmiczne; tworzy improwizacje ruchowe inspirowane wyliczankami, rymowankami i rytmizowanymi tekstami.

- Edukacji plastycznej:

- Uczeń: wykonuje prace i impresje plastyczne jako formy przekazania i przedstawienia uczuć, nastrojów i zachowań (np. prezent, zaproszenie); ilustruje sceny i sytuacje (realne i fantastyczne) inspirowane wyobraźnią, baśnią, opowiadaniem i muzyką; korzysta z narzędzi multimedialnych; tworzy przy użyciu prostej aplikacji komputerowej, np. plakaty, ulotki i inne wytwory (Dz.U. 2017, poz. 356).

Jak było napisane już wcześniej, wartości wpisane w warstwę socjologiczną człowieka to wartości moralno-społeczne. Wartości te mogą być przybliżone uczniom podczas realizacji treści głównie z zakresu:

- Edukacji społecznej:

- Uczeń: ocenia swoje postępowanie i innych osób, odnosząc się do poznanych wartości, takich jak: godność, honor, sprawiedliwość, obowiązkowość, odpowiedzialność, przyjaźń, życzliwość, umiar, powściągliwość, pomoc, zadośćuczynienie, przepraszanie, uznanie, uczciwość, wdzięczność oraz inne, respektowane przez środowisko szkolne; szanuje zwyczaje i tradycje różnych grup społecznych i narodów, przedstawia i porównuje zwyczaje ludzi, np. dotyczące świąt w różnych regionach Polski, a także w różnych krajach.

- Etyki:

- Uczeń: odkrywa, że współtworzy różne wspólnoty osób, np. rodzinę, klasę, państwo; ma świadomość, że każdej osobie ludzkiej, także jemu, należy się szacunek, że szacunkiem należy obdarzać także wspólnoty osób - rodzinę, klasę, naród (ojczyznę), w tym wspólnotę religijną - a także symbole tych wspólnot; określa, co jest dobre, a co jest złe $\mathrm{w}$ otaczającym go świecie i w świecie poznawanych tekstów oraz podaje uzasadnienie swojego zdania; odkrywa, że wspólnota osób, której jest członkiem, ustanawia swoje zasady (normy) i oczekuje ich respektowania; przestrzega zasad obowiązujących we wspólnocie osób, której jest członkiem (Dz.U. 2017, poz. 356).

Wartości powyższe mogą być przybliżane uczniom edukacji wczesnoszkolnej także w edukacji polonistycznej, muzycznej przez dobór odpowiednich tekstów literackich lub piosenek dla dzieci, których treść jest ich nośnikami. 
W kulturologiczną warstwę rozwoju człowieka wpisane są takie wartości, jak kultura i piękno. Wartość kultury ukazywana jest dzieciom w klasach I-III szkoły podstawowej podczas realizacji treści za zakresu:

- $\quad$ Edukacji polonistycznej:

- Uczeń: słucha uważnie wypowiedzi osób podczas uroczystości, koncertów, przedstawień, świąt narodowych i innych zdarzeń kulturalnych; przejawia zachowanie adekwatne do sytuacji; słucha tekstów interpretowanych artystycznie, szuka własnych wzorców poprawnej artykulacji i interpretacji słownej w języku ojczystym.

- Edukacji muzycznej:

- Uczeń: tańczy według układów ruchowych charakterystycznych dla wybranych tańców (w tym integracyjnych, ludowych polskich oraz innych krajów Europy i świata).

- Edukacji plastycznej:

- Uczeń: rozpoznaje i nazywa podstawowe gatunki dzieł malarskich i graficznych: pejzaż, portret, scena rodzajowa; nazywa wybrane przykłady dzieł znanych artystów: malarzy, rzeźbiarzy, architektów z regionu swego pochodzenia lub innych (Dz.U. 2017, poz. 356).

Piękno natomiast może ukazywane dzieciom przez realizację treści z zakresu edukacji polonistycznej, muzycznej, plastycznej czy też przyrodniczej. Chociaż treści zawarte w podstawie programowej nie eksponują w sposób bezpośredni wartości piękna, to wydaje się oczywiste jego odkrywanie w dziełach sztuk plastycznych i muzyce, ojczystym języku czy w świecie przyrody.

Ostatnią warstwą rozwoju człowieka jest warstwa światopoglądowa. Z tą warstwą wiążą się wartości najwyższe, ostateczne, z których najważniejsze jest szczęście, ale także godność, prawda, miłość, a dla ludzi wierzących wiara w Boga. Nie wszystkie są one jednak w podstawie programowej dla pierwszego etapu edukacyjnego wskazywane wprost. Największą szansę ukazania wartości najwyższych stwarza realizacja treści z zakresu etyki. W podstawie programowej czytamy m.in.:

- Etyka:

- Uczeń: ma świadomość, że jako człowiek posiada swoją niezbywalną godność oraz że wszystkie inne osoby posiadają taką godność; odkrywa wolność jako wartość przypisaną osobie, także osobie w jego wieku; dostrzega, że granice jego wolności wytycza godność i dobro innych osób, np. z kręgu rodziny, klasy, rówieśników; dostrzega, że każdy powinien brać odpowiedzialność za swoje wybory; dostrzega, że lepiej poznaje siebie, bardziej się rozwija i czerpie szczęście w relacji z innymi osobami niż w samotności; ma świadomość, że każdej osobie ludzkiej, także jemu, należy się szacunek, że szacunkiem należy obdarzać także 
wspólnoty osób - rodzinę, klasę, naród (ojczyznę), w tym wspólnotę religijną - a także symbole tych wspólnot; określa, co jest dobre, a co jest złe w otaczającym go świecie i w świecie poznawanych tekstów oraz podaje uzasadnienie swojego zdania; odróżnia szczęście od doraźnie odczuwanej przyjemności i poznaje, że dobro jest źródłem szczęścia własnego oraz innych osób; szanuje godność każdej osoby ludzkiej oraz swoją, wyraża swoim komunikatem werbalnym i niewerbalnym; uwzględnia coraz częściej godność i dobro innych osób, podejmując decyzję o działaniu (Dz.U. 2017, poz. 356).

Godność człowieka, wolność, dobro, szczęście to wartości szczególnie eksponowane w treściach programowych z zakresu etyki. Wiara w Boga - jako wartość zaliczana do wartości najwyższych - znajduje swoje miejsce głównie w Podstawie programowej katechezy Kościoła Katolickiego w Polsce.

\section{PODSUMOWANIE}

Podsumowując powyższe analizy, można zauważyć, że podstawa programowa dla I etapu edukacyjnego stwarza szansę wychowania ku wartościom w kontekście integralnego rozwoju dziecka w młodszym wieku szkolnym. Pomimo tego, że nie wszystkie wartości wpisane w poszczególne warstwy rozwoju człowieka wybrzmiały w sposób bezpośredni w treściach poszczególnych obszarów edukacyjnych, to realizacja podstawy programowej umożliwia nauczycielowi stworzenie takich sytuacji edukacyjnych, które te wartości wychowankom przybliżą. Istnieje więc wielka potrzeba namysłu i podjęcia działań w kierunku wychowania ku wartościom dzieci w młodszym wieku szkolnym. Przedstawiony materiał stanowi wstęp do dalszych, głębszych i szerszych analiz dotyczących budowania aksjosfery dzieci w wieku wczesnoszkolnym.

\section{LITERATURA}

Buk-Cegiełka M., 2013, Integralny rozwój i wychowanie dziecka w systemie wychowawczodydaktycznym Marii Montessori. Elementy teorii i praktyki. Lublin, Libropolis.

Chałas K., 2007, Wychowanie ku wartościom wiejskim jako szansa integralnego rozwoju wychowanka. Lublin, Wydawnictwo KUL.

Chałas K., 2011, Moc wychowawcza przypadkowych zdarzeń w świetle introcepcji wartości. Kielce-Lublin, Wydawnictwo Jedność. 
Chałas K., 2014, Edukacja elementarna w Polsce $w$ świetle integralnego rozwoju $i$ wychowania. „KERYKS”, 13.

Cichoń W., 1996, Wartości. Człowiek. Wychowanie. Kraków, Wydawnictwo Uniwersytetu Jagiellońskiego.

Denek K., 2000, Aksjologiczne aspekty edukacji szkolnej. Toruń, Wydawnictwo Adam Marszałek.

Hildebrand D. V., Kłoczowski J. A., Paściak J., Tischner J., 1984, Wobec wartości. Poznań, Wydawnictwo W drodze.

Jan Paweł II, 1991, Orędzie na XVIII Światowy Dzień Pokoju (01 I 1985). W: Wy jesteście moją nadzieja. Wybór wypowiedzi Ojca Świętego Jana Pawła II do młodzieży. Warszawa, Stowarzyszenie PAX, Centralny Zespół Młodych.

Kunowski S., 2004, Podstawy współczesnej pedagogiki. Warszawa, Wydawnictwo Salezjańskie.

Ostrowska K., W poszukiwaniu wartości. Gdańsk, Gdańskie Wydawnictwo Psychologiczne.

Piwowarski W., (red.), 1993, Słownik katolickiej nauki społecznej. Warszawa, Instytut Wydawniczy Pax, Wydawnictwo Misjonarzy Klaretynów Palabra.

Skrzydlewski P., 2016, Szczęście. W: K. Chałas, A. Maj (red.), Encyklopedia aksjologii pedagogicznej. Radom, POLWEN.

Rozporzadzenie Ministra Edukacji Narodowej z dnia 14 lutego 2017 r. w sprawie podstawy programowej wychowania przedszkolnego oraz podstawy programowej kształcenia ogólnego dla szkoły podstawowej, w tym dla uczniów $z$ niepetnosprawnościa intelektualna $w$ stopniu umiarkowanym lub znacznym, kształcenia ogólnego dla branżowej szkoły I stopnia, kształcenia ogólnego dla szkoły specjalnej przysposabiającej do pracy oraz kształcenia ogólnego dla szkoły policealnej (Dz.U. 2017, poz. 356).

\title{
THE CHANCES OF UPBRINGING TOWARDS VALUES
}

IN THE CURRENT CORE CURRICULUM IN THE LIGHT

OF INTEGRAL DEVELOPMENT OF YOUNGER SCHOOL-AGE CHILDREN

\begin{abstract}
In the present article the author raised the issue of upbringing younger school-age children towards values, their development in different aspects (biological, psychological, sociological, cultural and ideological). Not only the development of different aspects is important but also their integration. The article presents also groups of values connected with individual layers of human development. Hedonistic, vital and material values are connected with the biological layer, cognitive values are connected with the psychological layer, social and moral values - with the social layer, cultural values - with the cultural layer and ultimate values -
\end{abstract}


with the ideological layer. These groups are the basis for the analysis of the contents of the current core curriculum for the first educational stage. With this analysis, the author tried to answer the eponymous question: What chances for upbringing towards values does the current core curriculum create in the light of integral development of younger school-age children?

Keywords: integral development, upbringing towards values, early school education 